\title{
Fishing Tools in Java in Historical and Cultural Perspectives
}

\author{
Sri Indrahti ${ }^{1}$, Siti Maziyah ${ }^{2}$ \\ \{indrahti@gmail.com, mazy_muiz@yahoo.com\} \\ Department of History, Faculty of Humanities, Diponegoro University ${ }^{1,2}$ \\ J1. Prof. Soedarto, Tembalang, Semarang, 50275, Indonesia
}

\begin{abstract}
Fishing is one of the livelihoods in Java that causes the emergence of fishing gear that is different from one place to another. This article highlights the problem of fishing gear based on its history and culture. What is the history of fishing gear in Java? What culture is the background and caused by the fishing gear? Why is this fishing gear still sustainable? The results show that the variety of fishing gear is influenced by several cultural regions, namely inland areas, pond areas, and coastal areas. Based on various types of fishing gear, it also shows that fishing is a part-time job or the main job. In a community whose main job is fishing, a culture arises related to their fishing gear. The fishing gear is still sustainable until now because the tool is still used even though there are innovations in its manufacture.
\end{abstract}

Keywords: fishing gear; livelihood; history; culture; innovation.

\section{Introduction}

Cultural research is an endless study. Koentjaraningrat [1] states that culture has seven elements which include language, knowledge systems, social organizations, living equipment systems and technology, living livelihood systems, religious systems, and arts. The seven elements of culture are found in any culture, both in the simplest culture and at the highest cultural level. Furthermore, Koentjaraningrat stated that specifically, culture can be influenced by ethnicity, geographical area of culture, as well as the type of livelihood. It just likes what happened to the people of the North Coast of Java, especially in the people of Kedung Malang Village, Kedung Jepara District, and Wonokerto Kulon Village, Wiradesa District, Pekalongan.

The two research areas are fishing communities that have a distinctive culture which is different from the culture caused by other livelihood systems. Fishermen are one of the livelihoods whose main activity is fishing. This livelihood causes the emergence of fishing gear that is different from one place to another. This article highlights the problem of fishing gear based on its history and culture. What is the history of fishing gear in Java? What culture is the background and caused by the fishing gear? Why is this fishing gear still sustainable?

\section{Method}


This research is an analytical descriptive study. This study uses primary sources and secondary sources. Primary sources are archives or other data both textual and non-textual. Secondary sources are obtained from previous research results, and from various relevant literature.

In order to gather information related to traditional fishing gear, direct observation is carried out. The observation aims to obtain a more complete description of traditional fishing gear and the values contained to be developed as well as documenting the types of traditional fishing gear, historical background, supporting communities for traditional fishing gear, how to make and map the location of traditional fishing gear makers.

Research data were also collected using in-depth interview techniques. Interviews were carried out on all elements of stakeholders including sellers and makers of traditional fishing gear, Tourism Office, Bappeda, traditional fishing gear employers' organizations, users of traditional fishing gear, community, and relevant community leaders, and related associations

Sharpening the data and information collection is done by using FGD (Focus Group Discussion). In this FGD activity, each individual in groups asks each other, expresses opinions, perceptions, and beliefs about traditional fishing gear and traditional values contained in tool symbolization. The FGD gives freedom to participants who represent various groups of stakeholders simultaneously both sellers, communities and business actors who support activities, makers, users of traditional fishing gear, fishing organizations, relevant community leaders, and related agencies. Through FGD, access to traditional fishing gear groups can be obtained to be explored more deeply.

Anthropological approaches are also used by anthropologist as an effort to focus on ethnohistorical studies, which are various activities of society, culture, symbolic meanings, and values of local traditions which today still relate or reflect knowledge and life in the past that have cultural significance or local traditions [2].

The economic approach is used to analyze economic problems related to economic activity in its role to improve the standard of living and welfare of the community. The phenomenon of an economic approach is built on the common principles of thinking to describe a phenomenon with socio-economic problems. Economic, non-economic, socio-cultural factors greatly influence the economic behavior of the community [3].

Traditional fishing gear as an economic product certainly has demands and offers, where producers have the duty to produce a product to meet the demands. Consumers are users of traditional fishing gear. Consumers have needs and requests that must be fulfilled and fulfill these needs by means of money [4]. In micro terms, it is explained that traditional fishing gear has a positive impact: increasing the income of local people. The development of the fishing community around the site will increase community income.

All data collected through the methods and various approaches above will then be classified, connected or accumulated between data from one another, linked between primary sources and library sources or secondary sources as a form of interpretation. Then, all the data are synthesized in order to develop a model that can be applied.

\section{Results and Discussion}

\subsection{Traditional fishing gear in Jepara and Pekalongan}




\subsubsection{Traditional fishing gear in Jepara}

Traditional fishing gear in the village of Kedung Mulyo, Kedung Subdistrict, is very diverse. Of the total fishing gear, there are some that are still functioning, some are not functioning and some are experiencing innovation in the form and utilization. To find out the grouping, an inventory is needed as follows: seser, bubu, kepis, ajug, chart, net, arat, and dogol.

\subsubsection{Traditional fishing gear in Pekalongan}

Fishermen in Wonokerto Kulon village are broadly grouped into three categories, namely small fishermen, medium fishermen and skipper fishermen (Interview with Dorat, on 12 April 2018). For small fishermen, many use the traditional fishing gear. Whereas fishermen with large categories generally have their own vessels, as well as entrepreneurs who are hereditary, have fishing areas from the Strait of Karimata to the island of Natuna. In carrying out fishing activities, it lasts almost 3 (three) months. The results of the catch are generally sold at Tegal TPI, Pekalongan TPI, and TPI Juana. Santrang fishing gear, in general, is widely used to capture kecik fish such as pethek, sothong, and squid (Interview with Tardi on 12 April 2018).

\subsection{Culture of Fishermen Tradition in Kedung Malang Village Kedung Jepara District and in Wonokerto Kulon Village Wiradesa District Pekalongan}

The fishing community in Wonokerta village, $80 \%$ of the population is Muslim and still maintains traditions such as Nggalang boat, Tsakuran, and ziaroh as well as celebrating Islamic holidays, including Sedekah Laut, Rajaban and Mauludan (Interview with Karsan on April 12, 2018).

To fill in the days when not going to sea, the fishermen also carried out boats that repaired boats. To facilitate the work of repairing a boat, it is usually throwing a party (selametan) with grilled chicken dishes, egg dishes and fish and the like. The tradition of raising these boats besides being associated with the work of repairing boats, this party is also meant when someone buys other valuables, such as author and car that can also be used for work.

In addition to the slametan tradition, the fishing community also conducts pilgrimages regularly, both locally and to Kudus, Demak and Pekalongan. This pilgrimage is carried out individually and as a recitation group. This tradition is intended to get religious strength to lead a life full of tests and get the spirit of doing a fulfilling job with challenges. Fishermen work in the middle of the ocean, anything can happen so that it requires inner strength and physical strength to be able to survive, moreover the income that is often uncertain depending on natural conditions.

The tradition that is also routinely carried out by these fishing communities is tahlilan, carried out individually or by families every Friday night, as well as in groups, both a collection of Muslim groups, neighborhoods and village levels. Usually if done a collection every Friday once a week, whereas if done at the village level then it is carried out moving around the place of departure. 
This tahlilan activity usually does not stand alone, but there are recitations and to further encourage and motivate members, there are also a number of people who are relatively few. However, due to a large number of members between 100 people multiplied by IDR 5000, - if possible, around IDR 500,000. The amount for the village community is quite a lot.

\section{Conclusion}

The results showed that the variety of fishing gear was influenced by several cultural regions, namely inland areas, pond areas, and coastal areas. Based on various types of fishing gear it also shows that fishing is a part-time job or the main job. In a community whose main job is fishing, then a culture arises related to their fishing gear. The fishing gear is still sustainable until now because the tool is still used even though there are innovations in its manufacture.

\section{References}

[1] Koentjaraningrat. : Pengantar Ilmu Antropologi, Jakarta: PT Rineka Cipta (1990)

[2] Palmer, Richard E. : Hermenutika, Teori Baru Mengenai Interpretasi, terjemahan Musnur Hery, Yogyakarta: Pustaka Pelajar, pp. 7-8 (2003) ; Geertz Clifford, The Impact Of Culture, New York: Basic Books (1973)

[3] Sjafri Sairin, 2002. Pengantar Antropologi Ekonomi, Yogyakarta Pustaka Pelajar 2002).

[4] Ace Partadiredja, Pengantar Eko Wisata, Yogyakrta: BPFE (1985). 